\title{
Critical Thinking Skills of Environmental Changes: A Biological Instruction Using Guided Discovery Learning-Argument Mapping (GDL-AM)
}

\author{
Rizhal Hendi Ristanto* \\ Department of Biology Education, Universitas Negeri Jakarta, Jakarta, Indonesia \\ ORCID: 0000-0001-8655-2030 \\ Arin Sabrina Ahmad \\ Department of Biology Education, Universitas Negeri Jakarta, Jakarta, Indonesia \\ ORCID: 0000-0002-0100-7461
}

\author{
Ratna Komala \\ Department of Biology, Universitas Negeri Jakarta, Jakarta, Indonesia \\ ORCID: 0000-0002-1127-6235
}

Article history

Received:

04.03.2021

Received in revised form: 20.06.2021

Accepted:

27.06.2021

Key words:

Argument mapping,

Critical thinking skills,

Guided discovery.
Based on the development of education in Indonesia today, teachers still teach in ways that make students memorize lessons. A learning model is needed that can support students to think critically. One of the learning models that can support students to think critically is through guided discovery learning model with argument mapping. This study aims to find out the influence of guided discovery learning models with an argument mapping to develop critical thinking skills. The research method used was quasi experimental and pretest-posttest control group design, the sample of the study consisted of 66 students drawn from 89 Senior High School Jakarta. This sample was divided into two groups to assign the experimental and control group. The experimental group was exposed to guided discovery learning and argument mapping, while the control group with conventional learning. The result of independent sample t-test with a significance level of $\alpha=0.05$ experimental group showed that $\mathrm{p}$-value was 0.000 . It can be concluded that there is the influence of the guided discovery learning with argument mapping on senior high school students' critical thinking skills. The result of Normalized gain also show that the experimental group was effective to develop critical thinking skills $(\mathrm{N}$-gain $=0.45)$. Furthermore, the study found out that $\mathrm{N}$-gain for each indicator of critical thinking skills in the experimental group was higher than the control group. Basic clarification $(\mathrm{N}$-gain $=0.31)$, bases for decision $(\mathrm{N}$-gain $=0.68)$, inference $(\mathrm{N}$-gain $=$ $0.19)$, and advance clarification $(\mathrm{N}$-gain $=1.2)$ were reported. Guided discovery learning with argument mapping should be an alternative learning medium to develop critical thinking skills.

\footnotetext{
*Correspondency: rizhalhendi@unj.ac.id
} 


\section{Introduction}

Guided discovery learning (GDL) implementation in biological instruction aims to have students be capable of building their knowledge independently. GDL in biological instruction prioritizes student activities to develop knowledge integrally through teacher guidance and peer groups (Martineau, Traphagen, \& Sparkes, 2013; Pujiastuti \& Haryadi, 2020; Styers, Van Zandt, \& Hayden, 2018). Through the GDL model, biology teachers play a role as a motivator and instructor to assist students in finding biological concept in learning activities (Noviyanti, Rusdi, \& Ristanto, 2019; Styers et al., 2018). The GDL assists students up to two important criteria, namely: activation or construction of available knowledge to be utilized in creating new knowledge and integration of new information with prior information (Ristanto, Zubaidah, Amin, \& Rohman, 2017; Sartono, Rusdi, \& Handayani, 2018). Students require GDL learning model to deal with a case and identify core problem and questions to be answered (Großmann \& Wilde, 2019; Reynolds \& Chiu, 2013). The process of learning science in high school students will be better with the help of the teacher (Großmann \& Wilde, 2019; Suparini, Rusdi, \& Ristanto, 2020). Teacher assistance in solving cases and problem formulation helps students to achieve learning objectives through GDL (Harahap, Ristanto, \& Komala, 2020; Noviyanti et al., 2019).

The GDL process in the biological instruction also has positive impacts on students' critical thinking development and facilitates them to cultivate intellectual abilities and skills (Noviyanti et al., 2019; Reynolds \& Chiu, 2013). Moreover, it is proven to be able to enhance curiosity and skills of looking for the answers to high level problems (Miarsyah \& Ristanto, 2019; Sartono et al., 2018). Additionally, it is believed to be able to encourage students to analyze their knowledge (DeDonno, 2016; Ostrovsky, Poole, Sciortino, Eugene Stanley, \& Trunfio, 1991). It assists students in building and finding new biological concepts (Goode \& Halbritter, 2019; Lee, Reed, \& Laverty, 2012; Roth, 2008). Through the GDL implementation, students are trained to develop thinking skills that focus on comprehension (Großmann \& Wilde, 2019; Ramanujan, Zhou, \& Ramani, 2019). These skills are trained through problems solving (Casanoves, Salvadó, González, Valls, \& Novo, 2017; Orozco \& Yangco, 2016).

Critical thinking skills connect teacher and student interaction as reciprocal interaction and horizontal communication should exist in the learning process (Bustami, Riyati, \& Julung, 2019; Gündüz, Alemdăg, Yaşar, \& Erdem, 2016; Ristanto, Djamahar, Heryanti, \& Ichsan, 2020). Content in biology on critical thinking skills involve analysis, synthesis, and evaluation of biological concepts (Bustami, Syafruddin, \& Afriani, 2018; Muhlisin, Susilo, Amin, \& Rohman, 2016; Setiawati \& Corebima, 2017). It is important to teach critical thinking skills as critical thinking is a mental process (Duron, Limbach, \& Waugh, 2006; Mulnix, 2012; Saadé, Morin, \& Thomas, 2012). Students as individuals should be active and skillful in conceptualizing, applying, analyzing, synthesizing, and evaluating information to reach an answer or conclusion (Astuti, Wihardi, \& Rochintaniawati, 2020; Kuhn, 2007; Kurt, EkİcI, Aksu, \& Aktaş, 2013). Findings from various studies indicate that problem solving skills through learning like GDL contributes to students' critical thinking skills (Camacho \& Legare, 2015; Noviyanti et al., 2019; Setyorini, Sukiswo, \& Subali, 2011).

Besides GDL learning model, argument mapping application could also help empower critical thinking (Butchart et al., 2009; Kunsch, Schnarr, \& van Tyle, 2014). Argument mapping is a technique that facilitates its users in visualizing premises on which to draw conclusion in a logic (Eftekhari \& Sotoudehnama, 2018; Kunsch et al., 2014). The implementation of argument mapping could enhance critical thinking as well as recall better 
memories compared to learning without argument mapping (Harrell, 2008). Students are expected to acquire writing experiences by identifying main problems and searching for data in the form of facts, evidences, or information (Genlott \& Grönlund, 2013; Sørvik \& Mork, 2017).

The current learning objectives support learners to empower critical thinking skills that could be exerted in solving global issues (Akçay, 2009; Bustami et al., 2018). The issues are liferelated issues, such as climate change. The content of environmental changes is studied by students in Indonesia at grade 10. The objectives of the subject is that after learning the subject it could have positive impacts in sharpening critical thinking skills to solve natural events-related issues (Arozaq, Aman, \& Sunarhadi, 2016; Stevenson, Nicholls, \& Whitehouse, 2017). Competence must be achieved by learners referring to the National Education Standards Board in Indonesia i.e., students could analyze data of environmental changes, the causes and impacts on life, and formulate an idea of solving problems of environmental changes that occur in the surrounding environment. Critical thinking skills are essential for learners in mastering, encountering, and solving environmental change issues. The GDL stages from several research results show that they can improve students' critical thinking skills (Noviyanti et al., 2019; Suparini et al., 2020). There are no studies that test the integration of GDL and argument mapping and its influence on critical thinking skills. This research aims to analyze the influence of GDL model with argument mapping (GDL-AM) on critical thinking skills of environmental changes.

\section{Methods}

\section{Research Design}

This research utilized a quasi-experimental method. The research design was pretestposttest control group design (Sugiyono, 2012). The research independent variables consisted of GDL-AM learning model for experimental class and conventional learning, which is a learning model that is commonly applied in the content of environmental change, for the control class. The dependent variable was critical thinking skills of environmental changes. The research design is elaborated in Table 1.

Table 1. Pretest-Posttest Control Group Design

\begin{tabular}{llll}
\hline Group & Pretest & Treatment & Posttest \\
\hline Experimental Class & $\mathrm{O}_{1}$ & $\mathrm{X}$ & $\mathrm{O}_{3}$ \\
Control Class & $\mathrm{O}_{2}$ & $\mathrm{C}$ & $\mathrm{O}_{4}$ \\
\hline
\end{tabular}

\section{Population and Sample}

The research population included Grade 10 students of MIPA of Senior High School 89 Jakarta, Indonesia in an even semester of 2018/2019 academic year. The research samples were taken using random sampling method and 2 classes of Grade X MIPA were selected. One class assigned as an experimental class and the other as a control class. The class assignment carried out randomly with the assistance of the class biology teachers. The simple random sampling that resulted in 66 students of 72 students in each class was obtained from a calculation using Slovin formula. The equivalence of the experimental and control classes was carried out before determining the class, by using the average value of biology in the previous semester through the average test in each class. 


\section{Instrument}

Instruments utilized to measure students' critical thinking skills were in the form of an essay test that consisted of 13 questions with scores ranged from 0 to 5 . The instruments tested 36 students. Validation results using Pearson Product Moment generated 11 valid question items. The instrument reliability was calculated using Alpha coefficient formula (Cronbach's Alpha). Based on the calculation results, the instrument reliability value was 0.631, which is a high criterion. The grids of critical thinking skill instruments on environmental changes is described in Table 2. In addition to critical thinking skill test instruments, the research also developed questionnaires on learning implementation for teachers and students as well as response to GDL-AM learning for students in the experimental class.

Table 2. Instrument Grids of Critical Thinking Skill Test

\begin{tabular}{|c|c|c|c|}
\hline Aspect & Sub-aspect & Indicator & $\sum$ Questions \\
\hline \multirow[t]{6}{*}{ Basic clarification } & \multirow[t]{2}{*}{ Focusing the questions } & Identify or formulate questions & 1 \\
\hline & & $\begin{array}{l}\text { Identify or formulate possible } \\
\text { answer criteria }\end{array}$ & 1 \\
\hline & \multirow[t]{3}{*}{ Analyze arguments } & Identify conclusion & 1 \\
\hline & & $\begin{array}{l}\text { Identify existing/mentioned } \\
\text { reasons }\end{array}$ & 1 \\
\hline & & $\begin{array}{llll}\begin{array}{l}\text { Identify reasons not yet } \\
\text { mentioned }\end{array} & & & \\
\end{array}$ & 1 \\
\hline & $\begin{array}{l}\text { Ask or answer questions on an } \\
\text { explanation to understand the } \\
\text { clarification and its relations }\end{array}$ & Ask "why" questions & 1 \\
\hline $\begin{array}{l}\text { Consider the } \\
\text { credibility of } \\
\text { sources used (bases } \\
\text { for decision) }\end{array}$ & $\begin{array}{l}\text { Consider the credibility of a } \\
\text { source by observing and } \\
\text { contemplating the observation } \\
\text { results }\end{array}$ & $\begin{array}{l}\text { Consider opinions and provide } \\
\text { argumentation }\end{array}$ & 2 \\
\hline \multirow[t]{3}{*}{$\begin{array}{l}\text { Draw conclusion } \\
\text { (inference) }\end{array}$} & $\begin{array}{l}\text { Make an induction/deduction } \\
\text { and consider the } \\
\text { induction/deduction results }\end{array}$ & $\begin{array}{l}\text { Interpret questions and make a } \\
\text { generalization }\end{array}$ & 1 \\
\hline & \multirow{2}{*}{$\begin{array}{l}\text { Make and consider the } \\
\text { decision results }\end{array}$} & Provide reinforcement & 2 \\
\hline & & Think about alternatives & 1 \\
\hline \multirow[t]{2}{*}{$\begin{array}{l}\text { Advance } \\
\text { clarification }\end{array}$} & \multirow[t]{2}{*}{ Identify terms and definitions } & $\begin{array}{l}\text { Analyze definitions and terms } \\
\text { mentioned }\end{array}$ & 1 \\
\hline & & $\begin{array}{l}\text { Make examples required for } \\
\text { advance clarification from the } \\
\text { existing terms }\end{array}$ & 1 \\
\hline
\end{tabular}

\section{Procedures}

The research consisted of three stages, namely: preparation, implementation, and data processing. The first stage, preparation stage, included developing research instruments in the form of valid and high reliable critical thinking skill tests; compiled syllabus learning tools, learning plan, student worksheet, observation sheet of GDL-AM learning model implementation for teachers and students, and response questionnaires for students after the biological instructional process; and carried out sampling to be assigned as experimental and control classes. Data collection through pretest and posttest uses 14 critical thinking questions with indicators according to Table 2, while student responses are measured by providing a response questionnaire to GDL-AM learning with a total of 15 statements consisting of positive and negative statements. 
The initial implementation stage carried out by providing pretest for experimental and control classes. The pretest was intended for identifying the initial condition of students' critical thinking skills in relation to the content of environmental changes. It is followed by teaching students using GDL-AM in the experimental class. The GDL-AM learning stages are illustrated in Figure 1.

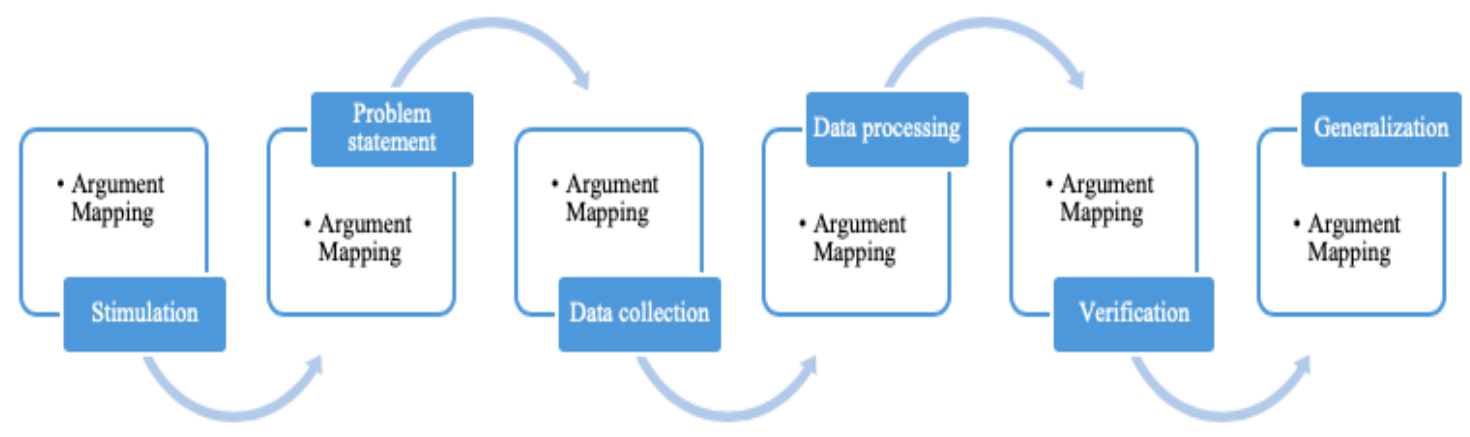

Figure 1. GDL-AM Stages

Figure 1 explains student learning using the GDL that consists of the following learning stages: stimulation, problem statement, data collection, data processing, verification, and generalization. Argument making was initiated in the problem statement stage and continued in the following stages. Once the learning process of the environmental changes completed, posttests were given to students in the experimental and control classes. The posttest aimed to find out the results of students' critical thinking skills concerning environmental changes. Thus, the influence of guided discovery learning model with argument mapping could be identified. The third stage was data processing elaborated in the analysis data section. The research process was carried out for four weeks, namely in the first week a pretest was carried out to students and provided information related to the preparation for the implementation of biology learning with GDL-AM, in the second and third weeks learning was carried out in the experimental and control classes. In the third week, post-test and student responses to learning were carried out.

\section{Data Analysis}

Data analysis utilized in the research comprised descriptive analysis technique in the form of calculation of mean, standard deviation, maximum value, and minimum value of each class. The percentage of learning implementation and the attainment of minimum completeness criteria value were also calculated in the research. The minimum completeness criteria is a minimum limit must be achieved by students in learning. The pretest and posttest results were analyzed to identify the influence of the GDL-AM learning model on critical thinking of environmental changes. Data obtained were analyzed using pre-requisite tests consisted of normality and homogeneity tests. The results of normality test using Kolmogorov-Smirnov and homogeneity test using F-test $(\alpha=0.05)$ are presented in Table 3. The normalized gain test was used to find out the enhancement of students' critical thinking skills and the hypothesis testing used statistical analysis of t-test used SPSS version 23 application. 
Table 3. Summary of normality test and homogeneity test results

\begin{tabular}{llllll}
\hline Test & Class & Test results & p value & $\boldsymbol{\alpha}$ & Description \\
\hline \multirow{2}{*}{ Normality } & \multirow{2}{*}{ Experiment } & Pretest & 0.203 & 0.05 & Normal \\
\cline { 2 - 5 } & & Posttest & 0.135 & 0.05 & Normal \\
\cline { 2 - 5 } & \multirow{2}{*}{ Control } & Pretest & 0.199 & 0.05 & Normal \\
& \multirow{2}{*}{ Experiment } & Posttest & 0.201 & 0.05 & Normal \\
\cline { 2 - 5 } & \multirow{2}{*}{ Homogeneity } & Pretest & 0.920 & 0.05 & Homogeneous \\
& \multirow{2}{*}{ Control } & Posttest & 0.488 & 0.05 & Homogeneous \\
& & Pretest & 0.920 & 0.05 & Homogeneous \\
& Posttest & 0.488 & 0.05 & Homogeneous \\
\hline
\end{tabular}

\section{Results and Discussion}

The results of students' critical thinking skill test of environmental changes could be observed from the pretest and posttest scores. Summary of the descriptive test is displayed in Table 4 that indicates the lowest and highest scores, mean score, standard deviation, and normalized gain.

Table 4. Data of Students' Critical Thinking Skill Test

\begin{tabular}{lllll}
\hline Data & GBL-AM & & Control & \\
\cline { 2 - 5 } & Pretest & Posttest & Pretest & Posttest \\
\hline Lowest score & 36.00 & 47.00 & 16.00 & 39.00 \\
Highest score & 82.00 & 93.00 & 74.00 & 82.00 \\
Mean & 53.24 & 75.21 & 39.33 & 63.30 \\
SD & 12.33 & 10.53 & 15.09 & 9.79 \\
\hline Normalized Gain & 0.45 & & 0.36 & \\
\hline
\end{tabular}

The calculation results of pretest and posttest scores against the minimum completeness criteria value of the environmental change learning in Senior High School Jakarta, Indonesia was 75. Based on the minimum completeness criteria value, it could be inferred that the percentage of the students' critical thinking skill of environmental changes in the GDL-AM class was higher than those in the control class. Summary of the grouping of completed (score >75) and non-completed (score $<75$ ) percentage in the pretest and posttest is illustrated in Figure 2.

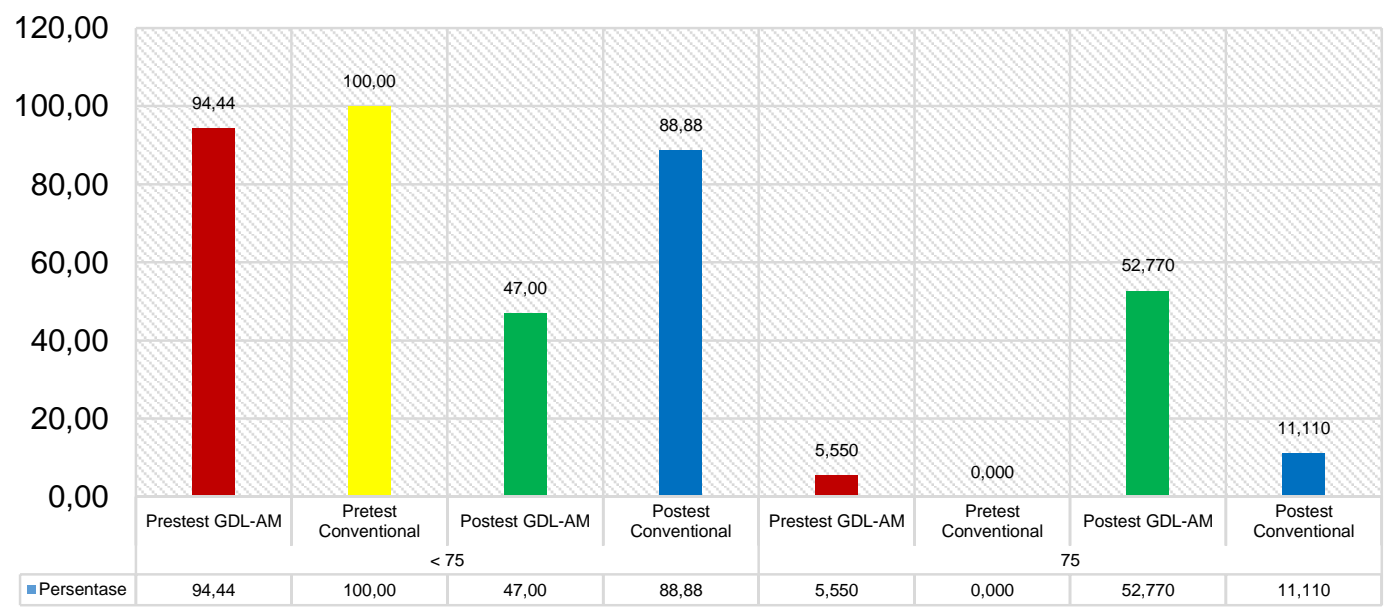

Figure 2. Percentage of Minimum Completeness Criteria of Pretest and Posttest Scores of Critical Thinking Skill of Environmental Changes in Experimental and Control Classes 
There were four critical thinking skill aspects of environmental change assessed in the research. The four aspects consisted of basic clarification, base for decision, inference, and advance clarification. Figure 3 indicates that the achievement of these aspects could be identified from the differences in the normalized gain of each aspect in the GDL-AM class and control class. The GDL-AM class acquired higher normalized gain than the control class for each critical thinking skill aspect. It was related to the mean of posttest score in the experimental class that was higher than those in the control class as indicated in Table 4.

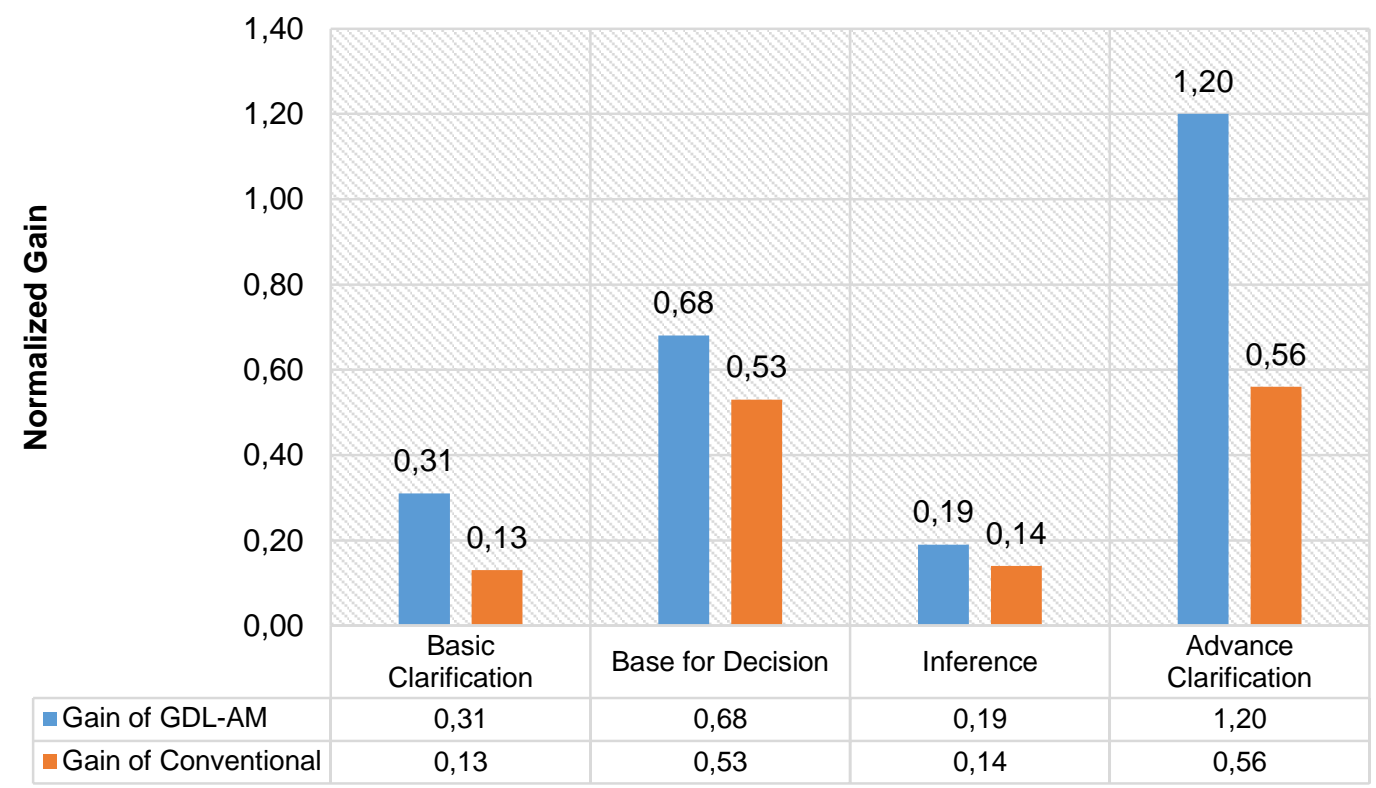

Figure 3. Achievement of Critical Thinking Skill Aspects in Experimental and Control Classes

The implementation of learning process by teachers and students in environmental change learning using GDL-AM and conventional methods was observed in two meetings. The first meeting (course I) discussed the sub-content of environmental damages, imbalance in environment, types of waste, and environmental pollution. In the second meeting (course II), students learned about the impact of environmental pollution, global warming, and adaptation and mitigation. Referring to the data in Figure 6, the implementation of learning by teachers and students using the GDL-AM was in a good category, whereas in the conventional class the implementation was in a poor category (Kohar, Jatmiko, \& Raharjo, 2017). 


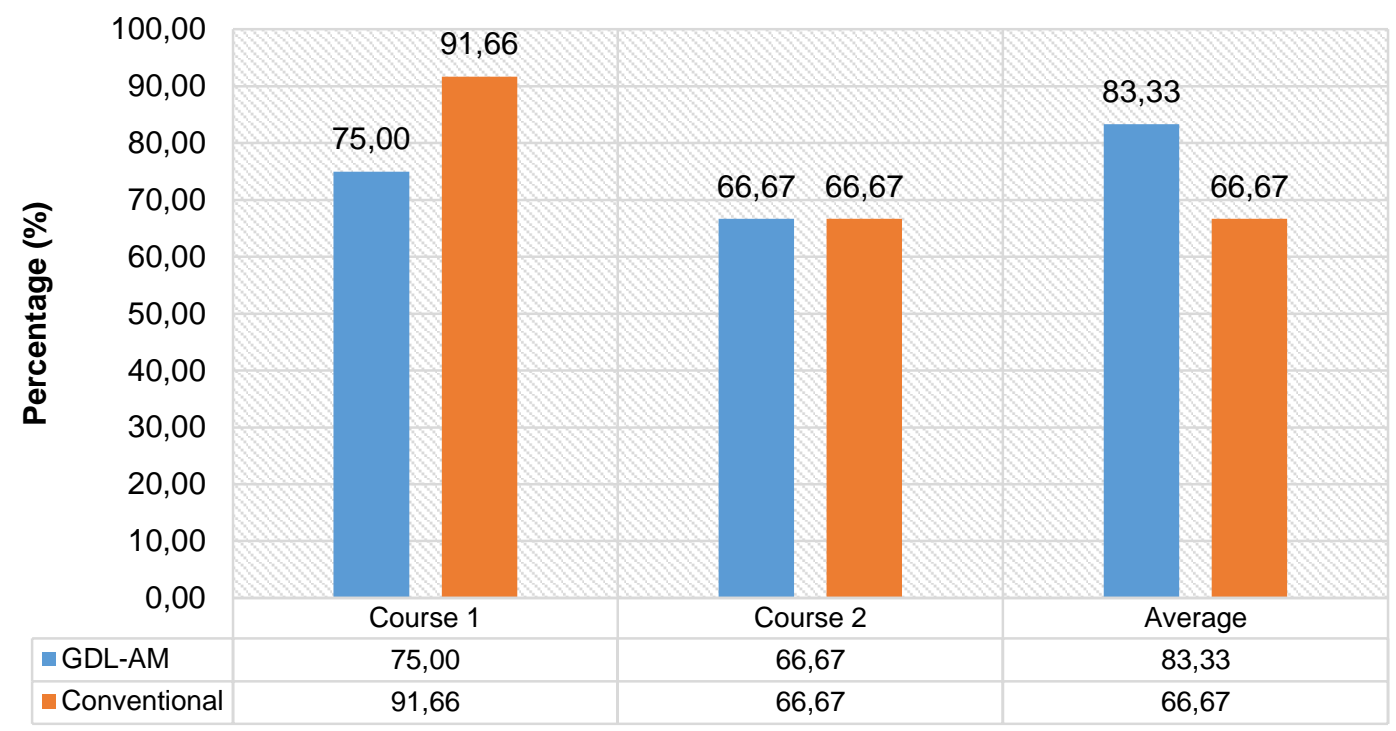

Figure 4. Percentage of Learning Process Implementation in Experimental and Control Classes

Response questionnaire answered by students consisted of 15 positive and negative statements on the implementation of the GDL-AM model. Eight statements were positive and seven other statements were negative. According to Table 5, the positive statements were mostly answered by students with agree and obtained the highest percentage of $49.88 \%$, whereas negative statements obtained disagree answer the most with a percentage of $49.35 \%$.

Table 5. Average Percentage of Students’ Response Questionnaire

\begin{tabular}{|c|c|c|c|c|}
\hline \multirow{2}{*}{ Statement } & \multicolumn{4}{|c|}{ Average (\%) } \\
\hline & SA & $\mathbf{A}$ & DA & SDA \\
\hline Positive & 22.32 & 49.88 & 21.61 & 6,15 \\
\hline Negative & 3.08 & 11.56 & 49.35 & 35,98 \\
\hline
\end{tabular}

Note: Strongly agree (SA), Agree (A), Disagree (DA), Strongly disagree (SDA)

The hypothesis testing carried out using statistical analysis of t-independent test was at $\alpha=$ 0.05 . The test used SPSS version 23 application. Based on the t-test results as presented in Table 6 , the pretest data obtained $p$ value $<\alpha$, which was $0.002<0.05$. It implied that there was a difference in the pretest result between the experimental class and control class. The ttest also carried out for the posttest data that resulted in a $p$-value $<\alpha,(0,000<0.05)$; hence, $\mathrm{H}_{0}$ was rejected meaning that there was an influence of the GDL-AM model on students' critical thinking skills of environmental change content.

Table 6. Summary of t-Independent test results on pretest and posttest data

\begin{tabular}{llllllll}
\hline Data & Class & $\mathbf{N}$ & Mean & SD & $\boldsymbol{\alpha}$ & p value & \multirow{2}{*}{ Result } \\
\hline \multirow{2}{*}{ Pretest } & Experiment & 33 & 50.86 & 11.33 & \multirow{2}{*}{0.05} & \multirow{2}{*}{0.002} & \multirow{2}{*}{$\mathrm{p}<\alpha$} \\
\cline { 2 - 8 } & Control & 33 & 40.00 & 15.09 & & & \multirow{2}{*}{ Posttest } \\
\cline { 2 - 8 } & Experiment & 33 & 74.06 & 10.53 & \multirow{2}{*}{0.05} & 0.000 & $\mathrm{p}<\alpha$ \\
\hline
\end{tabular}

Normalized Gain is a difference between posttest and pretest scores. The t-independent test of normalized gain was done in the research to find out the influence of the GDL-AM model on 
the enhancement of pretest and posttest scores of students' critical thinking skills of environmental changes. The calculation results are summarized and presented in Table 7.

Table 7. $t$ - Independent test of Normalized Gain

\begin{tabular}{lllllll}
\hline Class & N & Mean & SD & $\boldsymbol{\alpha}$ & p-value & Result \\
\hline GDL-AM & 33 & 23,03 & 12,05 & \multirow{2}{*}{0,05} & 0,038 & $\mathrm{p}<\alpha$ \\
\hline Control & 33 & 17,86 & 8,30 & & & \\
\hline
\end{tabular}

Table 7 indicates p-value $<\alpha(0.038<0.05)$; thus, rejecting $\mathrm{H}_{0}$, which meant that there was an influence of the guided discovery learning with argument mapping model on critical thinking skills of senior high school students in environmental change content. The normalized gain was a difference between pretest and posttest scores that indicated the enhancement of students' skills before and after the environmental change learning. The test carried out using SPSS version 23 application. The results are summarized in Table 8. Classes that learned using GDL-AM and conventional methods both had medium enhancement criteria. Students who learned using the GDL-AM, however, had higher normalized gain score than those in the control class.

Table 8. Normalized Gain Test

\begin{tabular}{lll}
\hline Class & Normalized Gain & Category \\
\hline GDL-AM & 0.45 & Medium \\
\hline Conventional & 0.36 & Medium \\
\hline
\end{tabular}

This research aimed to find out the influence of the GDL-MA model on students' critical thinking skills of environmental changes. The hypothesis testing results using t-test (Table 6 and 7) indicate that there was an influence of the GDL-MA on critical thinking skills of environmental changes. The research results were relevant to several previous research results related to the GDL and argument mapping with critical thinking skills (Butchart et al., 2009; Dwyer, Hogan, \& Stewart, 2015; Kunsch et al., 2014; Noviyanti et al., 2019; Reynolds \& Chiu, 2013).

The research carried out on environmental change content. Students were asked to convey alternatives of the solution to a problem, analyze impacts, and identify types of adaptation and mitigation that could be applied due to the environmental damages. The learning process implemented through reading articles on pollution issues in areas around Jakarta, the capital city of Indonesia that suffers the most from environmental issues in Indonesia. These articles were analyzed and students were asked to write in the form of argument mapping. Moreover, students also required to answer the critical thinking skill test related to environmental issues connected to the daily life. The environmental issues comprised air pollution and the impacts of global warming. It intended to encourage students to make an association and think about examples related to daily life using their sentences so as to empower their critical thinking skills (Bustami et al., 2018; Mungawanah, Supriyati, \& Marpaung, 2018). Topics on environmental changes could train students to think critically in encountering a real case by analyzing it, providing solutions accordingly, and solving problems in a case (Gündüz et al., 2016; Proulx, 2012; Saadé et al., 2012). It is in accordance with Biological instructional objectives in the 2013 Curriculum stating that in addition to empowering critical thinking skills, students are also expected to search for alternatives of current environmental change problems and apply these in daily life (Fuad, Zubaidah, Mahanal, \& Suarsini, 2017; Sartono et al., 2018). As a matter of fact, one of the objectives of science education is increasing individuals who have awareness on environment through improvement of environmental protection-related attitudes and behaviors (Ateş \& Gül, 2018; Schmitt-Harsh \& Harsh, 2013). 
Table 4 shows that the mean scores of pretest and posttest for the GDL-MA class were higher than those in the conventional class. The normalized gain test results in Table 7 and 8 also indicate that the GDL-MA class had higher normalized gain than the conventional class. In Figure 2, the class that learned using the GDL-MA experienced an increase in pretest and posttest score percentage based on the minimum completeness criteria of environmental change learning that was higher than those in the conventional class. Therefore, Figure 3 indicates that the normalized gain of the experimental class in each aspect of critical thinking skills was also higher than the control class. The enhancement of the critical thinking skills was influenced by the implementation of learning activities through the GDL-MA. Every learning activity that is packed in a learning model will have an impact on students' critical thinking skills (Harahap et al., 2020; Permana \& Chamisijatin, 2018). The stages in the GDLMA learning were more effective in supporting students' critical thinking skills. The GDL implementation focuses on direct learning experience through inquiry activity by analyzing and constructing understanding so as to enhance students' critical thinking skills (Abdisa \& Getinet, 2012; Kholifah, Rinanto, \& Ramli, 2015; Ramanujan et al., 2019). The influence of the learning enhancement could be analyzed based on the GDL model steps, namely: grouping, stimulation, problem statement, data collecting, data processing, verification, and generalization. The activity of argument mapping writing also contributes to critical thinking skill development (Dwyer et al., 2015).

The first step of the GDL learning model is grouping. The biology teacher forms a heterogeneous group of 5-6 students. Through the grouping students could discuss and exchange ideas during the learning thus better thinking skills (Harahap et al., 2020; Loes \& Pascarella, 2017) and they also create an argument mapping. Group learning in the GDL provides an opportunity for learners to cooperate that could develop their thinking skill and social skill (Kivunja, 2014). In the current research, the students were more active after the group formation by assigning task and responsibility to each group member. The discussion process occurred among the members which could help the group to find solution of environmental issue faster. Students are more active in a group to find an answer of an environmental issue (Gündüz et al., 2016; Martini, Rosdiana, Subekti, \& Setiawan, 2018; Orozco \& Yangco, 2016). A good discussion process could train critical thinking (Proulx, 2012). In fact, discussion in biological instruction is a skill that has orientation to help process in students to develop knowledge so that it can train better critical thinking skills (Casanoves et al., 2017; Gokhale, 2012).

The second step is stimulation. The GDL is a learning model that refers to stimulus, experiences, and existing examples and leads to rearranging or changing the obtained views into new invention (Großmann \& Wilde, 2019; Sartono et al., 2018). The stimulation stage in the current research was provided to students in the form of images and videos on environmental damages, environmental pollution, and global warming. Images and videos are believed to be able to increase awareness and curiosity toward the causes and impacts of environmental damages (Dewiyanti \& Kommers, 2005; Unin \& Bearing, 2016). Videos that display the environmental condition can be used as a stimulation to increase students' curiosity to find out the causes of environmental damages (Chang, Chung, \& Huang, 2016). Curiosity is deemed to be able to help students' cognitive process in learning (Browne \& Keeley, 2007). Stimulation in the form of images and videos display on environmental issues facilitates students to start an argument mapping. Visualization of issues could assist students' ability to identify problems (Durand et al., 2019). Problem identification activity presented using argument mapping helps students to find more problems to be examined (Dwyer et al., 2015). 
The third learning step is called problem statement. In this step, teachers ask each group to identify problems related to the videos displayed and formulated a hypothesis. This step supports critical thinking skill aspect of basic clarification that trains students to be able to identify and state problems in the form of hypothesis and problem formulation according to the articles read. The step also facilitates the process of argument mapping creation in the next step. Formulating a hypothesis from a problem formulation could assist students to think and write them (Ristanto et al., 2017). Critical thinking skill could also be trained through writing activities by analyzing a reading (Harahap et al., 2020; Muhlisin et al., 2016).

Further, the fourth and fifth steps include data collection and data processing. This starts with argument mapping after the students are trained in the previous GDL stages. In the data collection and data processing steps, students were asked to collect and process various supporting evidence, facts, and relations of an environmental problem with guidance from the teacher. Teacher guidance could help students to select problem relevance to the learning objectives (Martineau et al., 2013; Ristanto, Zubaidah, Amin, \& Rohman, 2018). The students required the evidence, facts, and relations from the data to create an argument mapping. The data collection and processing activities supported with argument mapping encourage students to be more skillful and foster critical thinking (Butchart et al., 2009; Davies, 2011). These steps are relevant to the critical thinking skill aspect of bases for decision. The relevance can be examined from its indicators, namely: considering a source by understanding its relations and explanations by analyzing arguments to search for evidence and facts required in the argument mapping.

Students at secondary schools have medium achievement in all aspects of critical thinking with a fairly high percentage (Bustami et al., 2019; Harahap et al., 2020). It affects the ownership of skills to exert information obtained. Therefore, the results of normalized gain in the bases for decision aspect for the GDL-MA class that was higher indicating that the data collecting and data processing steps (Figure 3) supported the students to consider data or sources used as a material for argument mapping on environmental issues that make them to have better critical thinking skills. Additionally, guidance from the teacher is also important for the success of this step (Ostrovsky et al., 1991) as error could occur in the decision making process on environmental issues encountered by the students. In the current research, teacher visited each group to confirm the understanding of environmental issues and argument mapping preparation. One of the teacher roles in the guided discovery learning model is taking control so that students can have the levels comprehension and capabilities to solve a problem (Fakhriyah, 2014; Großmann \& Wilde, 2019; Prastiwi, Sigit, \& Ristanto, 2019).

The sixth step is where students recheck the data obtained from previous learning stages, which is data collecting and data processing. In this stage, data obtained are rechecked and restudied, which is also called verification. Student activity in this stage includes verification through group discussion. Each group examines the literature and confirms it to the teacher. Materials for argument mapping are acquired from the existing articles. Nevertheless, students, in the process, must look for more materials to complete the evidence, facts, and relations regarding the environmental issues. Therefore, the verification step supports the critical thinking skill aspect of advance clarification (Noviyanti et al., 2019). As regards environmental change content, the skills related to students' ability to define environmental change as a term, assess the definition of environmental changes, and re-identify an assumption on factors and impacts occurred due to environmental changes. The students could recheck information from the reading that has been analyzed by exploring unknown definitions and terms or via evaluating which definition to be used from the articles or other 
sources.

The last step of the GDL model is generalization. This stage is a conclusion drawing step by students on environmental issues in accordance with the results generated from the learning. Generalization supports the critical thinking skill aspect of inference (Reynolds \& Chiu, 2013) required in the argument mapping. Argument mapping is a mapping to help visualize argument premises that illustrates the relationships to support conclusion (Chiang, Fan, Liu, \& Chen, 2016; Dwyer et al., 2015). Argument mapping encourages students to observe inference relationship between the evidence and facts from the impacts of environmental changes and evaluate inference on losses incurred due to environmental changes. Students may provide arguments that could train their critical thinking skills (Dwyer, Hogan, \& Stewart, 2014; Moon, 2007). It indicates that argument mapping and generalization learning steps could help students to think critically by drawing conclusion inductively from various data, evidence, facts and relations on factors and impacts of environmental changes.

The normalized gain test results of each critical thinking skill in the experimental class were higher than the control class as indicated in Figure 3. The highest normalized gain result was in the advance clarification aspect. In this aspect, the critical thinking skill instruments were related to adaptation and mitigation. The students were better in answering this aspect compared to other aspects as the sub-content is a new content studied by them and its scope is related to the daily life, such as climate change adaptation and air pollution. The students utilized smart phone application to retrieve information on climate and weather as well as on the air pollution level. The example of mitigation in the daily life included reducing plastic waste, planting trees, and using public transportation. As a consequence, the students were more capable of responding to these issues. In essence, Biological instruction must be interesting and fun and related to the daily life so that it could be implemented well and achieve its goal (Bustami et al., 2018; Kirby, Fleming-Davies, \& White, 2019).

In the aspects of basic clarification, bases for decision, and inference, the experimental class obtained higher normalized gain (Figure 3). It was explainable from the application of the GDL-MA in the learning process. The control class, on the other hand, implemented conventional learning with lecture method and PowerPoint utilization. In the GDL-MA class, the students were taught by asking them to formulate the problem and hypothesis; hence, they must first comprehend these and the process could train the basic clarification aspect. The GDL model steps of formulating problem and hypothesis demanded the students to analyze thus it could train their critical thinking (Reynolds \& Chiu, 2013). The GDL-MA learning required the students to look for evidence, facts, and relations that supported the argument mapping. This activity trained their critical thinking aspect of bases for decision. Whilst, in the control class, teachers played a significant role in explaining environmental changes; hence, the students received information by listening and sometimes through question and answer activity. In the class that applied a lecture method students tended to be satisfied by the teacher explanation and deemed as capable of searching for the necessary information on their own. Consequently, the critical thinking skills were less empowered (Fuad et al., 2017; Setiawati \& Corebima, 2017). The inference aspect in the GDL-MA class was higher. It was supported by the GDL-MA learning steps that facilitated the students to review in the verification stage by evaluating evidences and facts obtained to draw conclusion on environmental changes. As a result, the students who applied the GDL-MA acquired sources to draw better conclusions compared to those in the conventional class in which lecture learning took place. 
The learning implementation also supported the achievement of critical thinking skills (Djamahar, Ristanto, Sartono, \& Darmawan, 2020; Harahap et al., 2020; Lestari, Ristanto, \& Miarsyah, 2019). The high percentage of learning implementation indicates that the learning model syntax is well implemented (Ristanto et al., 2020); thus it could reinforce the attainment of critical thinking skills (Harahap et al., 2020). The learning implementation percentage in the GDL-MA class and the conventional class is illustrated in Figure 4. In the GDBL-MA class the average percentage of implementation was in a good category, whereas in the control class was in a poor category. The poor category in the control class was due to several factors, such as lack of motivation and discussion between the teachers and the students. The experimental class experienced an increase in the percentage. In the first meeting, discussion between the teacher and the students during the data collecting and processing step was still lacking; however, it improved in the second meeting. The lack of discussion could be linked to the unfamiliarity with the learning model applied. The learning media will meet the practicality qualification if the average percentage of learning implementation meets the criteria of good at minimum (Djamahar, Ristanto, Sartono, Ichsan, \& Muhlisin, 2018). Accordingly, the learning implementation plan that applied argument mapping as the learning media could be categorized as a learning medium that meets the practicality qualifications as it attains average percentage with a good category.

The students in the experimental class that applied the GDL-AM learning were given a response questionnaire after the learning process. As indicated in Table 5, response to the positive statements on the GDL-AM learning was indicated by students who dominantly agreed. Statements such as using the GDL-AM is interesting and not boring received the highest average percentage. It means that the learning model newly applied in the class considered interesting and different by the students compared to the commonly used learning (Djamahar et al., 2020; Ismirawati, Corebima, Zubaidah, Ristanto, \& Nuddin, 2020; Ismirawati, Corebima, Zubaidah, \& Syamsuri, 2018; Muhlisin, 2019)

Another statement, the GDL-AM learning model facilitates students to apply biology knowledge in the daily life, received a high average percentage. It can be interpreted that the students realized learning can be linked to the students' daily life; hence, it is applicable, especially in the environmental change content, which has become a current global issue. The GDL assists students to exert information to construct their understanding; therefore, content understanding becomes more meaningful for the students (Bahtiar \& Dukomalamo, 2019; Handoko, Sajidan, \& Maridi, 2016). Hence, it is expected that after the learning process students can apply the content studied, such as plastic waste reduction, plastic waste processing to maintain the balance of nature, and other content in the environmental change content that can be applied in the daily life.

\section{Conclusion}

The study results implied that the GDL-AM implementation was proven to be capable of influencing critical thinking skills on environmental changes and it was better than the control class. The GDL and argument mapping had characteristics that enabled students to develop way of thinking; thus, training their critical thinking skills. Another finding was that the GDL-AM implementation assisted the teacher in achieving learning objectives and students' responses to the GDL-AM learning suggested that the learning was able to increase their curiosity and interest in learning the environmental changes. The highest increase in the critical thinking skills through the GDL-AM learning was indicated in the advance clarification aspect. The GDL implementation requires more time thus better learning 
planning. The research holds a limitation in terms of the GDL-AM implementation that was in a short period, which was in two meetings. Therefore, it is recommended to conduct a research with longer implementation to further uncover the advantages and disadvantages of the GDL and argument mapping integration. Additionally, further research is required to test the effectiveness of the GDL-AM in the biology content other than environmental changes or through other 21 st century skill aspects.

\section{Acknowledgments}

The authors would like to sincerely express their gratitude to all parties who helped the research process. To Mrs. Dr. Diana Vivanti Sigit, Mrs. Dr. Mieke Miarsyah, and Mrs. Erna Heryanti who offered their recommendations and important contributions for the research. To the biology teachers and students of Senior High School 89 Jakarta who participated in the research.

\section{References}

Abdisa, G., \& Getinet, T. (2012). The effect of guided discovery on students' Physics achievement. Latin-American Journal of Physics Education, 6(4), 530-537.

Akçay, B. (2009). Problem-based learning in science education. Journal of Turkish Science Education, 6(1), 26-36.

Arozaq, M., Aman, \& Sunarhadi, M. A. (2016). Implementation of reading guide strategy in global climate change material for enhancement of student learning outcome. International Journal of Active Learning, 2(2), 82-89. https://doi.org/https://doi.org/10.15294/ijal.v2i2.10803

Astuti, L., Wihardi, Y., \& Rochintaniawati, D. (2020). The development of web-based learning using interactive media for science learning on levers in human body topic. Journal of Science Learning, 3(2), 89-98. https://doi.org/10.17509/jsl.v3i2.19366

Ateş, H., \& Gül, K. S. (2018). Investigating of pre-service science teachers' beliefs on education for sustainable development and sustainable behaviors. International Electronic Journal of Environmental Education, 8(2), 105-122. Retrieved from https://dergipark.org.tr/en/download/article-file/478057

Bahtiar, \& Dukomalamo, N. (2019). Basic science process skills of biology laboratory: improving through discovery learning. Biosfer: Jurnal Pendidikan Biologi, 12(1), 8393. https://doi.org/https://doi.org/10.21009/biosferjpb.v12n1.83-93

Browne, M. N., \& Keeley, S. M. (2007). Asking the right questions: a guide to critical thinking. Analysis. https://doi.org/10.1002/1521-3773(20010316)40:6<9823::AIDANIE9823>3.3.CO;2-C

Bustami, Y., Riyati, Y., \& Julung, H. (2019). Think talk write with pictured cards on human digestive system: impact of critical thinking skills. Biosfer: Jurnal Pendidikan Biologi, 12(1), 13-23. https://doi.org/https://doi.org/10.21009/biosferjpb.v12n1.13-23

Bustami, Y., Syafruddin, D., \& Afriani, R. (2018). The implementation of contextual learning to enhance biology students' critical thinking skills. Jurnal Pendidikan IPA Indonesia, 7(4), 451-457. https://doi.org/10.15294/jpii.v7i4.11721

Butchart, S., Bigelow, J., Oppy, G., Forster, D., Serrenti, A., Korb, K., \& Gold, I. (2009). Improving critical thinking using web based argument mapping exercises with automated feedback. Australasian Journal of Educational Technology, 25(2), 268291. https://doi.org/10.14742/ajet.1154

Camacho, D., \& Legare, J. (2015). Opportunities to create active learning techniques in the classroom. Journal of Instructional Research, 4(2015), 38-45. https://doi.org/10.9743/JIR.2015.5 
Casanoves, M., Salvadó, Z., González, Á., Valls, C., \& Novo, M. T. (2017). Learning genetics through a scientific inquiry game. Journal of Biological Education, 51(2), 99-106. https://doi.org/10.1080/00219266.2016.1177569

Chang, R. C., Chung, L. Y., \& Huang, Y. M. (2016). Developing an interactive augmented reality system as a complement to plant education and comparing its effectiveness with video learning. Interactive Learning Environments, 24(6), 1245-1264. https://doi.org/10.1080/10494820.2014.982131

Chiang, K. H., Fan, C. Y., Liu, H. H., \& Chen, G. D. (2016). Effects of a computer-assisted argument map learning strategy on sixth-grade students' argumentative essay reading comprehension. Multimedia Tools and Applications, 75, 9973-9990. https://doi.org/10.1007/s11042-015-2904-y

Davies, M. (2011). Concept mapping, mind mapping and argument mapping: What are the differences and do they matter? Higher Education, 62, 279-301. https://doi.org/10.1007/s10734-010-9387-6

DeDonno, M. A. (2016). The influence of IQ on pure discovery and guided discovery learning of a complex real-world task. Learning and Individual Differences, 49, 1116. https://doi.org/10.1016/j.lindif.2016.05.023

Dewiyanti, S., \& Kommers, P. (2005). Virtual reality for spatial topics in biology. International Journal of Continuing Engineering Education and Lifelong Learning. https://doi.org/10.1504/ijceell.2004.004577

Djamahar, R., Ristanto, R. H., Sartono, N., \& Darmawan, E. (2020). Approaches to Respiratory and Excretion Systems Teaching: An Innovative Learning through Cirsa. Universal Journal of Educational Research, 8(6), 2204-2210. https://doi.org/10.13189/ujer.2020.080602

Djamahar, R., Ristanto, R. H., Sartono, N., Ichsan, I. Z., \& Muhlisin, A. (2018). Cirsa: designing instructional kits to empower 21st century skill. Educational Process: International Journal, 7(3), 200-208. https://doi.org/10.22521/edupij.2018.73.4

Durand, M. de T., Restini, C. B. A., Wolff, A. C. D., Faria Jr., M., Couto, L. B., \& Bestetti, R. B. (2019). Students' perception of animal or virtual laboratory in physiology practical classes in PBL medical hybrid curriculum. Advances in Physiology Education, 43(4), 451-457. https://doi.org/10.1152/advan.00005.2019

Duron, R., Limbach, B., \& Waugh, W. (2006). Critical Thinking Framework For Any Discipline. International Journal of Teaching and Learning in Higher Education, 17(2), 160-166. https://doi.org/10.1016/j.nepr.2006.09.004

Dwyer, C. P., Hogan, M. J., \& Stewart, I. (2014). An integrated critical thinking framework for the 21st century. Thinking Skills and Creativity, 12, 43-52. https://doi.org/10.1016/j.tsc.2013.12.004

Dwyer, C. P., Hogan, M. J., \& Stewart, I. (2015). The effects of argument mapping-infused critical thinking instruction on reflective judgement performance. Thinking Skills and Creativity, 16, 11-26. https://doi.org/10.1016/j.tsc.2014.12.002

Eftekhari, M., \& Sotoudehnama, E. (2018). Effectiveness of computer-assisted argument mapping for comprehension, recall, and retention. ReCALL, 30(3), 337-354. https://doi.org/10.1017/S0958344017000337

Fakhriyah, F. (2014). Penerapan problem based learning dalam upaya mengembangkan kemampuan berpikir kritis mahasiswa. Jurnal Pendidikan IPA Indonesia, 3(1), 95101. https://doi.org/10.15294/jpii.v3i1.2906

Fuad, N. M., Zubaidah, S., Mahanal, S., \& Suarsini, E. (2017). Improving junior high schools' critical thinking skills based on test three different models of learning. International Journal of Instruction, 10(01), 101-116. https://doi.org/10.12973/iji.2017.1017a 
Genlott, A. A., \& Grönlund, Å. (2013). Improving literacy skills through learning reading by writing: The iWTR method presented and tested. Computers \& Education, 67, 98104. https://doi.org/10.1016/j.compedu.2013.03.007

Gokhale, A. A. (2012). Collaborative learning enhances critical thinking. Journal of Technology Education, 634-636. https://doi.org/10.21061/jte.v7i1.a.2

Goode, A. B. C., \& Halbritter, D. (2019). Entomological research in the classroom: the dispersal of biological control agents. The American Biology Teacher, 81(4), 242-247. https://doi.org/https://doi.org/10.1525/abt.2019.81.4.242.

Großmann, N., \& Wilde, M. (2019). Experimentation in biology lessons: guided discovery through incremental scaffolds. International Journal of Science Education, 41(6), 759-781. https://doi.org/10.1080/09500693.2019.1579392

Gündüz, A. Y., Alemdağ, E., Yaşar, S., \& Erdem, M. (2016). Design of a problem-based online learning environment and evaluation of its effectiveness. The Turkish Online Journal of Educational Technology, 15(3), 49-57. https://doi.org/10.1017/CBO9781107415324.004

Handoko, A., Sajidan, \& Maridi. (2016). Pengembangan modul biologi berbasis discovery learning (part of inquiry spectrum learning-wenning) pada materi bioteknologi kelas xii Ipa di sma negeri 1 magelang tahun ajaran 2014/2015. Jurnal Inkuiri, 5(3), 144154. Retrieved from http://jurnal.fkip.uns.ac.id/index.php/sains

Harahap, L. J., Ristanto, R. H., \& Komala, R. (2020). Getting critical thinking about ecosystem: How impact and responses of students about the CirGi learning model? Biosfer: Jurnal Pendidikan Biologi, 13(1), 86-100. https://doi.org/10.21009/biosferjpb.v13n1.86-100

Harrell, M. (2008). No computer program required: Even pencil-and-paper argument mapping improves critical-thinking skills. Teaching Philosophy, 31(4), 351-374. https://doi.org/10.5840/teachphil200831437

Ismirawati, N., Corebima, A. D., Zubaidah, S., Ristanto, R. H., \& Nuddin, A. (2020). Implementing ercore in learning: Will metacognitive skills correlate to cognitive learning result? Universal Journal of Educational Research, 8(4), 51-58. https://doi.org/10.13189/ujer.2020.081808

Ismirawati, N., Corebima, A. D., Zubaidah, S., \& Syamsuri, I. (2018). Ercore learning model potential for enhancing student retention among different academic ability. Egitim Arastirmalari - Eurasian Journal of Educational Research. https://doi.org/10.14689/ejer.2018.77.2

Kholifah, A. N., Rinanto, Y., \& Ramli, M. (2015). Kajian penerapan model guided discovery learning disertai concept map terhadap pemahaman konsep siswa sma kelas xi pada materi sistem imun. Bio-Pedagogi, 4(1), 12-18.

Kirby, C. K., Fleming-Davies, A., \& White, P. J. T. (2019). The figure of the day: A classroom activity to improve students' figure creation skills in biology. The American Biology Teacher, 81(5), 317-325. https://doi.org/10.1525/abt.2019.81.5.317

Kivunja, C. (2014). Teaching students to learn and to work well with 21st century skills: unpacking the career and life skills domain of the new learning paradigm. International Journal of Higher Education, 4(1), 1-11. https://doi.org/10.5430/ijhe.v4n1p1

Kohar, S., Jatmiko, B., \& Raharjo. (2017). Pengembangan perangkat pembelajaran berbasis inkuiri terbimbing menggunakan simulasi phet untuk mereduksi miskonsepsi siswa. Pendidikan Sains Pascasarjana Universitas Negeri Surabaya, 6(2), 1289-1301.

Kuhn, D. (2007). A Developmental Model of Critical Thinking. Educational Researcher. https://doi.org/10.3102/0013189x028002016 
Kunsch, D. W., Schnarr, K., \& van Tyle, R. (2014). The use of argument mapping to enhance critical thinking skills in business education. Journal of Education for Business, 89(8), 403-410. https://doi.org/10.1080/08832323.2014.925416

Kurt, H., Ekİ̀İ, G., Aksu, Ö., \& Aktaş, M. (2013). The most important concept of transport and circulatory systems: Turkish biology student teachers' cognitive structure. Educational Research and Reviews, 8(17), 1574-1593. https://doi.org/10.5897/ERR2013.1566

Lee, E. A., Reed, B., \& Laverty, C. (2012). Preservice Teachers' Knowledge of Information Literacy and Their Perceptions of the School Library Program. Behavioral and Social Sciences Librarian. https://doi.org/10.1080/01639269.2012.657513

Lestari, P., Ristanto, R. H., \& Miarsyah, M. (2019). Metacognitive and conceptual understanding of pteridophytes: development and validity testing of an integrated assessment tool. Indonesian Journal of Biology Education, 2(1), 15-24.

Loes, C. N., \& Pascarella, E. T. (2017). Collaborative learning and critical thinking: testing the link. Journal of Higher Education, 88(5), 726-753. https://doi.org/10.1080/00221546.2017.1291257

Martineau, C., Traphagen, S., \& Sparkes, T. C. (2013). A guided inquiry methodology to achieve authentic science in a large undergraduate biology course. Journal of Biological Education, 47(4), 240-245. https://doi.org/10.1080/00219266.2013.764345

Martini, Rosdiana, L., Subekti, H., \& Setiawan, B. (2018). Strengthening students' characters and ecopreneurship through science, environment, technology, and society course. Jurnal Pendidikan IPA Indonesia, 7(2), 162-171. https://doi.org/10.15294/jpii.v7i2.14338

Miarsyah, M., \& Ristanto, R. H. (2019). Memberdayakan keterampilan mengembangkan soal hots pada guru biologi di kabupaten bekasi. BAKTIMAS: Jurnal Pengabdian Pada Masyarakat, 1(4), 151-159. $\quad$ Retrieved from https://ojs.serambimekkah.ac.id/index.php/BAKTIMAS/article/view/1718

Moon, J. (2007). Critical thinking: An exploration of theory and practice. Critical Thinking: An Exploration of Theory and Practice. https://doi.org/10.4324/9780203944882

Muhlisin, A. (2019). Reading, mind mapping, and sharing (RMS): Innovation of new learning model on science lecture to improve understanding concepts. Journal for the Education of Gifted Young Scientists, 7(2), 323-340. https://doi.org/10.17478/jegys.570501

Muhlisin, A., Susilo, H., Amin, M., \& Rohman, F. (2016). Improving critical thinking skills of college students through RMS model for learning basic concepts in science. AsiaPacific Forum on Science Learning and Teaching, 17(1), 1-24.

Mulnix, J. W. (2012). Thinking Critically about Critical Thinking. Educational Philosophy and Theory. https://doi.org/10.1111/j.1469-5812.2010.00673.x

Mungawanah, K., Supriyati, Y., \& Marpaung, M. A. (2018). The Influence of Contextual Learning Model and Critical Thinking to Science Literacy of High School First Year Students. Journal of Physics: Conference Series, 1108(1), 1-7. https://doi.org/10.1088/1742-6596/1108/1/012124

Noviyanti, E., Rusdi, R., \& Ristanto, R. H. (2019). Guided discovery learning based on internet and self concept: enhancing student's critical thinking in biology. Indonesian Journal of Biology Education, 2(1), 7-14. https://doi.org/10.31002/ijobe.v2i1.1196

Orozco, J. A., \& Yangco, R. T. (2016). Problem-based learning: effects on critical and creative thinking skills in biology. Asian Journal of Biology Education, 9, 1-10.

Ostrovsky, B., Poole, P. H., Sciortino, F., Eugene Stanley, H., \& Trunfio, P. (1991). Learning science through guided discovery: liquid water and molecular networks. Physica A: 
Statistical Mechanics and Its Applications, 177(1-3), 281-293. https://doi.org/10.1016/0378-4371(91)90165-9

Permana, F. H., \& Chamisijatin, L. (2018). Project-based learning through edmodo: improving critical thinking and histology concepts. Biosfer: Jurnal Pendidikan Biologi, 11(1), 58-69. https://doi.org/10.21009/biosferjpb.v11n2.90-100

Prastiwi, L., Sigit, D. V., \& Ristanto, R. H. (2019). Relationship between academic ability and environmental problem-solving skill: a case study at adiwiyata schools in tangerang city, indonesia. Üniversitepark Bülten, 8(1), 76-86. https://doi.org/10.22521/unibulletin.2019.81.6

Proulx, G. (2012). Integrating Scientific Method \& Critical Thinking in Classroom Debates on Environmental Issues. The American Biology Teacher, 66(1), 26-33. https://doi.org/10.2307/4451613

Pujiastuti, H., \& Haryadi, R. (2020). The use of augmented reality blended learning for improving understanding of food security in universitas sultan ageng tirtayasa: A case study. Jurnal Pendidikan IPA Indonesia, 9(1), 59-69. https://doi.org/10.15294/jpii.v9i1.21742

Ramanujan, D., Zhou, N., \& Ramani, K. (2019). Integrating environmental sustainability in undergraduate mechanical engineering courses using guided discovery instruction. Journal of Cleaner Production, 207, 190-203. https://doi.org/10.1016/j.jclepro.2018.09.191

Reynolds, R., \& Chiu, M. M. (2013). Formal and informal context factors as contributors to student engagement in a guided discovery-based program of game design learning. Learning, Media and Technology, 38(4), 429-462. https://doi.org/10.1080/17439884.2013.779585

Ristanto, R. H., Djamahar, R., Heryanti, E., \& Ichsan, I. Z. (2020). Enhancing students ' biology-critical thinking skill through CIRC-Based scientific approach (Cirsa). Universal Journal of Educational Research, 8(4A), 1-8. https://doi.org/10.13189/ujer.2020.081801

Ristanto, R. H., Zubaidah, S., Amin, M., \& Rohman, F. (2017). Scientific literacy of students learned through guided inquiry. International Journal of Research \& Review, 234(5), 23-30. Retrieved

from https://www.ijrrjournal.com/IJRR_Vol.4_Issue.5_May2017/IJRR004.pdf

Ristanto, R. H., Zubaidah, S., Amin, M., \& Rohman, F. (2018). From a reader to a scientist: Developing cirgi learning to empower scientific literacy and mastery of biology concept. Biosfer: Jurnal Pendidikan Biologi, 11(2), 90-100. https://doi.org/10.21009/biosferjpb.v11n2.90-100

Roth, C. E. (2008). Paul F-Brandwein lecture 2006: Conservation education for the 21st century and beyond. Journal of Science Education and Technology. https://doi.org/10.1007/s10956-006-9023-5

Saadé, R. G., Morin, D., \& Thomas, J. D. E. (2012). Critical thinking in E-learning environments. Computers in Human Behavior. https://doi.org/10.1016/j.chb.2012.03.025

Sartono, N., Rusdi, R., \& Handayani, R. (2018). Pengaruh pembelajaran process oriented guided inquiry learning (pogil) dan discovery learning terhadap kemampuan berpikir analisis siswa sman27 Jakarta pada materi sistem imun. Biosfer: Jurnal Pendidikan Biologi, 10(1), 58-64. https://doi.org/10.21009/biosferjpb.10-1.8

Schmitt-Harsh, M., \& Harsh, J. A. (2013). The development and implementation of an inquiry-based poster project on sustainability in a large non-majors environmental science course. Journal of Environmental Studies and Sciences. https://doi.org/10.1007/s13412-012-0090-z 
Setiawati, H., \& Corebima, A. D. (2017). Empowering critical thinking skills of the students having different academic ability in biology learning of senior high school through pq4r-tps strategy. The International Journal of Social Sciences and Humanities Invention, 4(5), 3521-3526. https://doi.org/10.18535/ijsshi/v4i5.09

Setyorini, U., Sukiswo, \& Subali, B. (2011). Penerapan model problem based learning untuk meningkatkan memampuan berpikir kritis siswa smp. Jurnal Pendidikan Fisika Indonesia, 7(1), 52-56. https://doi.org/10.15294/jpfi.v7i1.1070

Sørvik, G. O., \& Mork, S. M. (2017). Scientific literacy as social practice: Implications for reading and writing in science classrooms. Nordic Studies in Science Education, 11(3), 268. https://doi.org/10.5617/nordina.987

Stevenson, R. B., Nicholls, J., \& Whitehouse, H. (2017). What Is Climate Change Education? Curriculum Perspectives, 37, 67-71. https://doi.org/10.1007/s41297-017-0015-9

Styers, M. L., Van Zandt, P. A., \& Hayden, K. L. (2018). Active learning in flipped life science courses promotes development of critical thinking skills. CBE Life Sciences Education, 17(3), 1-13. https://doi.org/10.1187/cbe.16-11-0332

Sugiyono. (2012). Metode penelitian kuantitatif kualitatif dan R\&D. Bandung: Alfabeta.

Suparini, S., Rusdi, R., \& Ristanto, R. H. (2020). Guided discovery-blended learning (GDBL) for critical thinking skill empowerment: A learning strategy in human excretory system. Biosfer, 13(2), 266-279. https://doi.org/10.21009/biosferjpb.v13n2.266-279

Unin, N., \& Bearing, P. (2016). Brainstorming as a way to approach student-centered learning in the ESL classroom. Procedia - Social and Behavioral Sciences, 224, 605-612. https://doi.org/10.1016/j.sbspro.2016.05.450 